Tarling: Journal of Language Education

Vol. 5, No. 1, Juni 2021

http://ejournal.iainpurwokerto.ac.id/index.php/tarling/index

\begin{tabular}{|ll|l|}
\hline Submitted $:$ 2021-01-01 & Accepted $: 2021-07-03$ \\
\hline Revised $:$ 2021-06-29 & Published $: 2021-07-19$ \\
\hline
\end{tabular}

\title{
Model Pembelajaran Flipped Classroom dalam Pembelajaran Ketrampilan Membaca di MTs Al- Hikmah Brebes
}

Kanza Rufaida $^{1}$, Muassomah ${ }^{2}$

${ }^{12}$ Universitas Islam Negeri Maulana Malik Ibrahim Malang

1Kanzarufaida20@gmail.com, ${ }^{2}$ muassomah@bsa.uin-malang.ac.id

\begin{abstract}
This research aims to determine the application of Flipped Classroom in learning reading skills, and determine its effectiveness in learning reading skills. This research uses descriptive qualitative. This research shows the application of the Flipped Classroom model in learning reading skills with reference to indicators that must be mastered. With this learning model, students are able to understand the reading text correctly, to translate the text, and to retell it in their own language. The researchers concluded that the application of the Flipped Classroom can improve students' reading comprehension.
\end{abstract}

Keywords: Flipped Classroom; reading skills; learning model; Arabic language 


\begin{abstract}
Abstrak
Penelitian ini bertujuan untuk mengetahui penerapan Flipped Classroom dalam pembelajaran ketrampilan membaca, dan mengetahui keefektifitasannya dalam pembelajaran ketrampilan membaca. Penelitian ini menggunakan kualitatif deskriptif. Penelitian ini menunjukkan adanya penerapan model flipped classroom dalam pembelajaran ketrampilan membaca dengan acuan indicator yang harus dikuasai. Dengan model ini siswa mampu memahami teks bacaan dengan tepat, mampu menerjemahkan teks bacaan, dan mampu menceritakan ulang dengan bahasanya sendiri. Peneliti menyimpulkan bahwa penerapan model flipped classroom dapat meningkatkan pemahaman teks bacaan siswa.

Kata kunci : Flipped Classroom; Ketrampilan Membaca; Model pembelajaran; Bahasa Arab
\end{abstract}

\title{
A. Pendahuluan
}

Pembelajaran Bahasa Arab yang tumbuh dan berkembang turut mewarnai wajah pendidikan Indonesia. Dalam perkembangannya, dukungan dan antusiasme harus digerakkan dari berbagai kalangan. Tantangan dan permasalahan belajar bahasa Arab di Indonesia hanya bisa diatasi oleh pihak tertentu saja. Pendekatan, metode dan model pembelajaran yang berbeda perlu dikembangkan melalui praktik pembelajaran di sekolah dan lembaga pengajaran Arab lainnya. Peran guru berubah sesuai dengan karakteristik siswa pada era ini karena guru tidak lagi hanya menyediakan materi tetapi juga sebagai desainer pendidikan, kolaborator, peneliti, dan mitra belajar siswa. Untuk itu, teknik dan model pembelajaran di kelas dapat disesuaikan dengan kebutuhan siswa dengan memperhatikan tujuan pembelajaran yang telah direncanakan.

Saat ini kita menghadapi perubahan sosial dan teknologi yang cepat. Perubahan ini menimbulkan masalah sistemik pada budaya dan struktur organisasi pada Lembaga pendidikan. Salah satu masalahnya adalah persentase siswa dan guru yang terus meningkat. Keadaan ini menyebabkan perlu adanya perubahan gaya belajar di Lembaga Pendidikan, termasuk pembelajaran bahasa Arab (Oktaria and Hamidi 2019). 
Ketrampilan membaca merupakan salah satu dari empat keterampilan bahasa lainnya, yaitu keterampilan menyimak, berbicara, membaca, dan menulis. Ketepatan ucapan adalah keterampilan produktif yang membutuhkan banyak upaya untuk dikuasai. Oleh karena itu metode dan teknik pembelajaran yang digunakan harus selalu mengikuti perkembangan zaman (Sa'diyah and Halimatus 2019). Keempat keterampilan berbahasa ini merupakan keterampilan yang saling terintegrasi dalam proses pengajaran dan pembelajaran. Untuk mampu merespon pembicaraan, pendengar harus bisa memahami pesan yang disampaikan pembicara, sehingga kedua keterampilan berbicara dan menyimak harus dilibatkan. Demikian halnya ketika kita menerima pesan dalam bentuk tertulis, maka seseorang harus bisa membaca dan memahami isi tulisan atau pesan tersebut yang dibekali dengan stock kosa kata yang memadai (Suriaman and Dewi 2019).

Berdasarkan data yang didapat pada semester lalu selama pembelajaran Bahasa Arab berlangsung sejauh ini presentase dalam memahami teks bacaan kurang memuaskan, siswa masih kesulitan dalam menemukan ide pokok ataupun gagasan utama dan indicator lainnya yang ada pada ketrampilan membaca. Begitu juga, pembelajaran yang selama ini dilakukan lebih terfokus kepada guru, yakni dengan metode konvensional.

Dengan adanya permasalahan tersebut perlu adanya inovasi system pembelajaran yang sebelumnya terpusat pada guru (teacher centered) menjadi pembelajaran yang terfokus pada kegiatan siswa (students centered). Sebagaimana yang tertulis pada Undang-undang Sistem Pendidikan Nasional Nomor 20 tahun 2003 menyatakan bahwa pembelajaran adalah berlangsungnya hubungan atau interaksi antara siswa dengan guru dan sumber belajar yang ada pada lingkungan. Pernyataan ini mensyaratkan pada guru harus dapat menguasai hakikat dari amteri pembelajaran yang akan diberikan dan juga menerapkan model pembelajran yang dapat merangsang kemampuan siswa untuk belajar (Alexander and Judy, n.d.). Menurut Iswadi, Hepratiwi dan Sudirman bahwa berkualitasnya suatu pembelajaran itu sangat berpegang pada strategi, metode maupun teknik 
dalam kegiatan pembelajaran berlangsung, guru sebagai penanggung jawab atas keadaan kelas yang kondusif agar menciptakan pembelajaran yang optimal (Iswadi, Herpratiwi, and Sudirman 2013).

Berdasarkan permasalahan yang peneliti temukan, penelitian ini dimaksudkan untuk melengkapi dan memperkuat penelitian yang telah dilakukan sebelumnya. Dengan mengamati, penulis ingin mengetahui, menganalisis, dan menerapkan model baru dalam pembelajaran bahasa Arab khususnya dalam ketrampilan membaca untuk memaksimalkan keterampilan siswa dalam membaca. Dalam hal ini peneliti menggunakan model Flipped Classroom dalam pembelajaran ketrampilan membaca untuk meningkatkan kemampuan siswa dalam memahami teks bacaan dengan cara mensinergikan teori dengan aplikasi. Oleh karena itu, tujuan dari penelitian ini adalah untuk Mengetahui penerapan menggunakan model Flipped Classroom dalam pembelajaran ketrampilan membaca dan mengetahui efektivitas model Flipped Classroom dalam pembelajaran ketrampilan membaca.

Flipped Classroom adalah model pembelajaran yang berpusat pada siswa dalam guna memaksimalkan efektifitas kegiatan belajar mengajar. Selama ini sebagian banyak guru masih menggunakan model ceramah yang menggambarkan pembelajaran berfokus pada guru. Kemudian bergeser dengan model alternatif yakni Flipped Classroom. Menurut Johnson (2013) Flipped Classroom adalah model pembelajaran yang mengurangi kuantitas penjelasan secara langsung namum mengoptimalkan interaksi secara langsung. Strategi ini mengoptimalkan pemanfaat tekhnologi yang dapat mendorong materi pembeljaran tambahan untuk siswa dengan mengakses baik online ataupun offline dimana saja dan kapan saja. Sementara itu kegiatan belajar dikelas dimanfaatkan untuk berdiskusi bertukar fikiran dengan teman-teman mereka (Johnson 2013).

Dengan kata lain Flipped Classroom adalah kebalikan dari prosedur pembelajaran tradisional, karena biasanya dilakukan di kelas dan dilakukan di rumah dan biasanya dilakukan di rumah sambil mengerjakan pekerjaan 
rumah atau pekerjaan rumah di kelas. Oleh karena itu strategi ini dinamakan pembelajaran kelas terbalik, pada kelas terbalik materi diberikan terlebih dahulu dengan cara mengunggah materi ke website pada blog atau media sosial seperti whatsapp dan botel dalam bentuk video edukasi yang harus diunduh atau diakses secara online dan dipelajari sebelumnya. Siswa di rumah atau di luar kelas. Sedangkan sesi pembelajaran digunakan di kelas untuk diskusi kelompok dan kerja kerja. (Danker 2015).

Flipped classroom memastikan penggunaan waktu guru secara optimal selama kelas, di mana guru dapat menilai level siswa di awal sesi, kemudian merancang kegiatan kelas dengan fokus pada klarifikasi apa yang sulit untuk dipahami, dan kemudian mengawasi kegiatan mereka dan memberikan dukungan yang sesuai kepada mereka yang masih belajar. Perlu penguatan. Dengan sistem ini diharapkan tingkat pemahaman dan pencapaian pendidikan semua siswa akan sangat tinggi, karena guru memperhitungkan perbedaan individu antar peserta didik. Dan karena video dianggap sebagai salah satu fondasi dasar dalam pola ini, maka dapat dikatakan bahwa strategi Flipped Classroom adalah salah satu metode pendidikan di mana teknologi berperan lebih besar dalam memecahkan masalah kesenjangan antara kajian teoritis sains dan sisi aplikasinya, karena merupakan salah satu solusi teknis modern untuk mengatasi gangguan belajar tradisional (Zauhy 2014).

Dari hasil studi penelitian, banyak ahli menggunakan bermacam metode pembelajaran untuk meningkatkan proses Pendidikan. Adapun salah satunya yaitu menggunakan pembelajaran Flipped Classroom dalam meningkatkan ketrampilan membaca siswa. Adapun penelitian yang dilakukan oleh Iftitahur Rohmah dalam penelitiannya yang menitikberatkan pada keterampilan menulis, Fenomena yang terjadi saat ini menujukkan rendahnya kualitas proses dan hasil pembelajaran menulis bahasa Arab. Kesulitan yang dihadapi siswa yaitu minimnya kosakata serta kurangnya pemahaman terhadap penyusunan kalimat yang benar. Penyebab lain adalah kurangnya pembiasaan menulis disekolah karena alokasi waktu 
yang singkat. Sehingga pembelajaran menulis kurang maksimal. Dalam hal ini penulis menawarkan sebuah solusi melalui pembelajaran Flipped classroom yang merupakan strategi yang dapat diberikan oleh pendidik dengan cara meminimalkan jumlah instruksi langsung dalam praktek mengajar mereka sambil memaksimalkan interaksi satu sama lain. Strategi ini memanfaatkan teknologi yang menyediakan tambahan yang mendukung materi pembelajaran bagi siswa yang dapat diakses secara online/offline. Hal ini membebaskan waktu kelas yang sebelumnya telah digunakan untuk pembelajaran. peneliti menerapkan Model Pembelajaran Flipped Classroom dalam Meningkatkan Maharah Kitabah Siswa Kelas VIII MTs. Bilingual Muslimat NU Pucang Sidoarjo (Rohmah 2016) .

Menurut Wijaya dalam artikelnya memperihatkan bahwa pembelajaran melalui Model Ruang Kelas Terbalik dapat berjalan lebih efektif dari sebelumnya, yaitu ceramah, tim, dan model pendidikan ini dapat ini meningkatkan hasil belajar dan memotivasi siswa. Terbukti lebih banyak mahasiswa yang mengikuti pembelajaran melalui soal-soal dan materi tambahan yang telah mereka persiapkan sebelumnya, berbeda dengan model perkuliahan dimana mahasiswa hanya memberi makna dan mendengarkan penjelasan dari dosen membuat mereka mengantuk (Wijaya and Hasanah 2019).

Hasil penelitian ini sampai pada kesimpulan bahwa pembelajaran bahasa Arab menggunakan Flipped classroom dapat memotivasi siswa untuk belajar bahasa Arab. Akan tetapi peneliti mencoba menerapkan menggunakan flipped classroom dalam pembelajaran keterampilan membaca pada siswa Madrasah Tsanawiyyah Al-Hikmah Brebes.

\section{B. Metode Penelitian}

Dalam metodologi penelitian ini, penulis akan memaparkan empat tahapan penting, yaitu jenis penelitian, sumber dan teknik pengumpulan data, teknik analisis data, dan teknik validasi data. Adapun penjabaran dari 
masing-masing poin sebagai berikut:

1. Jenis Penelitian

Penelitian yang digunakan metode kualitatif deskriptif. Menurut (Arikunto, 2006, h.55) metode ini sering digunakan untuk kondisi yang apa adanya, tidak dibuat-buat datanya. penelitian kualitatif deskriptif bersifat eksploratif atau developmental dalam penggambaran dan membuat kesimpulan. Penelitian deskriptif bermaksud menjelaskan atau mepresentasikan detail dari masalah yang ada dalam penelitian, dari penelitian ini akan ditemukan akar masalah yang akan dibahasa dan juga meberikan jalan keluar untuk masalah yang ada. Penelitian ini mendeskripsikan penerapan model Flipped Classroom dalam pembelajaran keterampilan membaca pada siswa Madrasah Tsanawiyyah Al-Hikmah Brebes. Adapun data primer bersumber pada hasil wawancara kepada kepala madrasah, ketua penguatan Bahasa Arab, dan buku panduan program penguatan Bahasa Arab. Sedangkan data sekunder berupa hasil observasi dan wawancara kepada siswa Madrasah Tsanawiyyah Al-Hikmah Brebes.

\section{Teknik Pengumpulan Data}

Menurut Sutrisno Hadi dalam (Gusmadi 2014) menyatakan bahwa sebagian dari beberapa penelitian itu tergantung bagaimana cara pengambilan data. Dari situlah apabila cara pengambilan datanya baik maka akan berpengaruh pada hasil penelitian. Teknik pengumpulan data pada penelitian ini berupa metode wawancara, observasi, dan dokumentasi. Dalam wawancara dilakukan kepada beberapa personil sebagai informan, diantaranya: Guru Bahasa Arab Madrasah Tsanawiyyah Al-Hikmah Brebes Brebes selaku penanggung jawab dari kegiatan tersebut. Siswa diwawancara untuk menggali informasi tentang, kekurangan serta kelebihan selama proses kegiatan berlangsung. Kemudian peneliti melakukan observasi lapangan dengan tujuan untuk meninjau serta mengamati langsung model Flipped Classroom dalam pembelajaran keterampilan membaca pada siswa Madrasah Tsanawiyyah Al-Hikmah Brebes tersebut. Berikutnya metode 
terakhir yang digunakan adalah dokumentasi, yang berupa absensi siswa dan daftar nilai siswa.

\section{Teknik Validasi Data}

Setelah data terkumpul, tahap selanjutnya adalah validitasi data. Dalam penelitian kualitatif, suatu data bisa dikatakan valid jika tidak muncul suatu perbedaan yang di teliti dengan apa yang terjadi di tempat yang diteliti.(Sugiyono 2019) .

4. Teknik Analisis Data

Menurut Miles dan Huberman (Sugiyono, 2019, h.135) bahwa aktivitas dalam analisis data dalam penelitian kualitatif dilakukan secara interaktif melalui tiga tahapan, yaitu data reduction, contoh data, dan conclusion drawing atau verification. Mereduksi data yang artinya menyimpulkan, serta memilah dan menentukan kepentingan data, dan juga polanya. Pada penelitian ini, kami mencantumkan dulu dari hasil suatu wawancara, observasi dan dokumentasi dalam bentuk rangkuman, kemudian bisa memilih suatu data yang kita butuhkan. Sedangkan data display merupakan suatu data yang memudahkan dalam menafsirkan suatu yang kemungkinan terdapat adanya kesimpulan. Setalah mereduksi data, mengadakan pengelompokkan suatu data dan mengerjakan data data yang selarasa dengan yang diteliti yaitu penerapan model Flipped Classroom dalam pembelajaran keterampilan membaca. Adapun tahap terakhir adalah conclusion drawing atau verivication. Di bagian ini peneliti ringkasan yang dapat ditarik data-data yang telah direduksi dan sebelumnya sudah di kelompokkan. Lalu memaparkan hasil penelitian tersebut secara lengkap dan jelas tentang model Flipped Classroom dalam pembelajaran keterampilan membaca pada siswa Madrasah Tsanawiyyah Al-Hikmah Brebes. 
Model Pembelajaran Flipped Classroom dalam Pembelajaran...

\section{Hasil dan Pembahasan}

\section{Penerapan Menggunakan Model Flipped Classroom dalam Pembelajaran Ketrampilan Membaca}

Flipped Classroom bagian dari pembelajaran Blended ( menggunakan dua interaksi baik tatap muka maupun online). Penelitian yang dilakukan terhadap kegiatan siswa pada saat proses pembelajaran berlangsung dengan model Flipped Classroom dalam kegiatan memahami teks bacaan, telah menunjukkan perkembangan penguasaan siswa terhadap materi yang diberikan. Kegiatan siswa menunjukkan sikap yang lebih aktif dan konsisten yang dapat dilihat dari awal pembelajaran. Proses pembelajaran model Flipped Classroom terdiri dari tiga kegiatan yakni Pre-Class, In Class dan Out Of Class. Sebelum kegiatan pembelajaran kelas dimulai siswa harus sudah mempelajari materi yang akan di diskusikan . disini siswa harus memiliki kemapuan mengingat (Remembering) dan mengerti (Understanding) materi yang akan dibahas. Dengan begitu ketika kegiatan dalam kelas dimulai siswa sudah dapat menerapkan atau mengaplikasikan dan menganalisis materi dengan aktivitas yang ada dalam kelas . Lalu berlanjut dengan proses evaluasi yang mana siswa mengerjakan tugas sebagai kegiatan setelah pembelajaran berakhir.

Setelah di atas dijelaskan kegiatan pelaksanaan flipped classroom secara garis besar, selanjutnya adalah Tahap-tahap penerapan Flipped Classroom dalam kegiatan pembelajaran ketrampilan membaca.

Pertama, sebelum kegiatan pembelajaran di kelas, guru memberikan materi dalam bentuk video pembelajaran lalu guru memjelaskan tujuan pembelajaran dan juga memaparkan materi yang akan dipelajari secara garis besar kemudian guru menginstruksikan tugas yaitu membuat ringkasan dari video tersebut. 


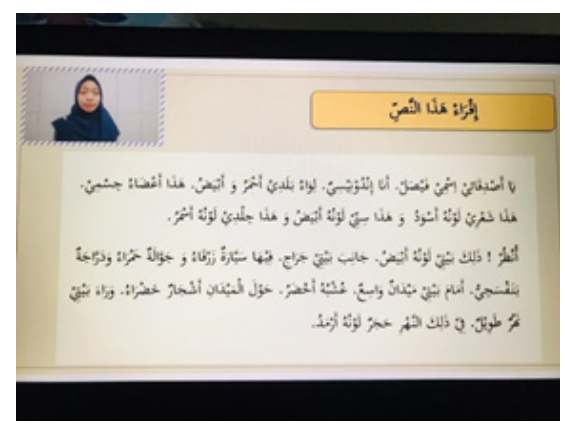

Gambar 1. Tahap Kegiatan Sebelum Pembelajaran

Kedua, guru membentuk kelompok yang mana ada 4-5 anggota dalam satu kelompknya, kemudian mereka membahas dan berdiskusi terkait materi yang di pelajari melalui video yang sudah ditonton.

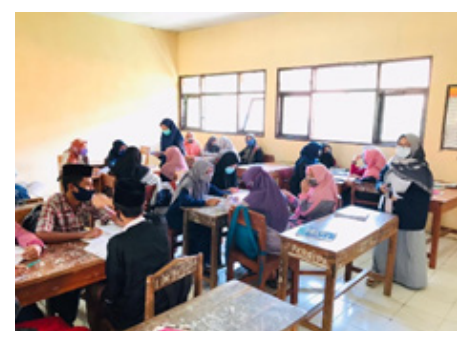

Gambar 2. Guru Membentuk Kelompok

Ketiga, guru melakukan tanya jawab dan memberikan latihan dalam pemecahan masalah menggunakan buku pegangan siswa dan siswa menyelsaikannya dengan berdiskusi dengan teman satu kelompoknya.

Berikut contoh tanya jawab yang diberikan kepada siswa perkelompoknya.

\begin{tabular}{|ll|}
\hline مالون بيت \\
\hline ما لون سيّارة ؟ & مالون سنّي ؟ \\
\hline r. & \\
\hline
\end{tabular}


Keempat, setelah kegiatan diskusi selesai guru meminta perwakilan kelompok untuk mempresentasikannya dan begitu pun kelompok yang lain menanggapi.
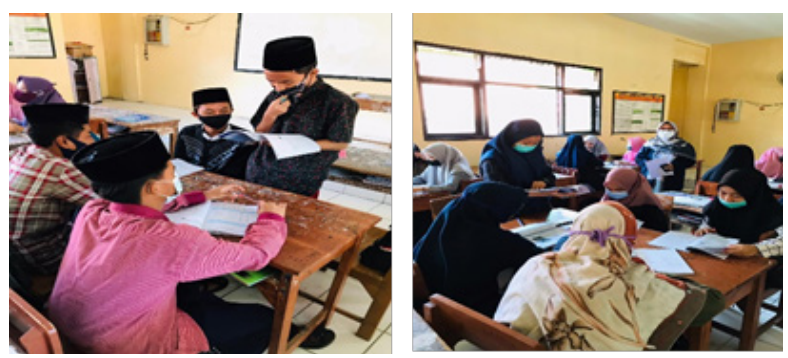

Gambar 3. Kegiatan Diskusi Kelompok

Kelima, untuk mengetahui sampai mana pemahaman siswa maka guru memberikan soal dan juga memberikan video untuk pertemuan yang akan datang.

Berikut contoh soal yang diberikan sesuai dengan materi yang di video

\begin{tabular}{|c|c|}
\hline 1. & ما لون لو اء بلد اندونيسيا ؟ \\
\hline r. & ما لون شعر فيصل ؟ \\
\hline r. & ما لون عشب ؟ \\
\hline
\end{tabular}

\section{Efektivitas Model Flipped Classroom Dalam Pembelajaran Ketrampilan Membaca}

Peningkatan ketrampilan dalam membaca merupakan peningkatan yang sangat penting dalam penelitian ini, guna mengetahui sejauh mana terkait dengan pemahaman siswa pada suatu teks bacaan dalam memenuhi indicator dalam ketrampilan membaca ,yaitu mampu membaca dan memahami teks bacaan dengan tepat, mampu menerjemahkan teks 
bacaan, dan juga tau posisi kata per kata dan dapat bercerita ulang dengan menggunakan bahasanya sediri (Mustofa 2011).

Dalam penerapan model flipped classroom peneliti melakukan mengamati ketrampilan membaca siswa dengan observasi. Observasi dilakukan dalam empat Indikator. peneliti menyimpulkan dari pengamatan yang sudah dilakukan dalam penerapan model Flipped Classroom sebagai berikut:

Indikator pertama: siswa mampu membaca teks Arab dengan bacaan yang benar, pada kemapuan ini, siswa sebagian besar sudah mampu membaca teks bahasa arab dengan benar, walaupun mesti harus banyak latihan membaca bacaan teks Arab.

Indikator kedua : siswa mempunyai pemahaman bacaan yang tepat, pada indicator ini siswa mengalami peningkatan dalam pemahaman teks bacaan, Misalnya, siswa dapat menentukan ide pokok dari isi teks bacaan tersebut. Hal ini menujukkan siswa memahami teks bacaan dengan benar. Yang sebelumnya saat guru memerintahkan mencari ide pokok dari suatu teks bacaan siswa masih kebingungan.

Indikator ketiga : siswa mampu menerjemahkan bacaan dengan benar, pada indikator ini belum begitu terlihat peningkatan yang signifikan, karena mungkin siswa harus memperbanyak mufrodat yang di kuasai.

Indikator keempat : siswa dapat menceritakan ulang dengan bahasanya sendiri, pada aspek ini terlihat peningkatan siswa secara signifikan yang mana saat siswa diminta untuk mempresentasikan hasil ringkasan yang di baca, mereka dapat menyampaikannya dengan bahasa nya sendiri.

Hasil observasi menunjukkan adanya peningkatan sikap tanggungjawab dan ketrampilan belajar yang lebih baik daripada penggunaan model pembelajaran biasa. Dengan begitu dapat diartikan bahwa model pembelajaran model Flipped Classroom dengan pemanfaatan teknologi dapat meningkatkan aspek kognitif, afektif, dan psikomotor. 
Aktivitas guru dalam penerapan model Flipped Classroom menghasilkan peningkatan pada setiap pertemuannya. Pembelajaran Flipped Classroom ini menjadikan adanya hubungan antar siswa dengan siswa maupun antar siswa dengan guru. Hal tersebut bisa dilihat dengan kegiatan guru selama proses pembelajaran dalam menyediakan kegiatan belajar siswa, tetapi juga dapat mengontrol pendominasian kelas. Di dalam kelas, guru dapat mengendalikan ruang dan sarana prasaran dalam pembelajaran, menjalankan kegiatan pembelajaran, menagtur interaksi siswa, dan terbuka dalam bersikap dan mendorong perilaku positif siswa.

Penilaian yang dilakukan dalam penerapan model Flipped Classroom ini tidak hanya dilakukan pada akhir pembelajaran namun dilakukan juga pada proses kegiatan belajar mengajar berlangsung.

Dari Hasil wawancara dengan guru, sejatinya guru merasa sanagt terbantu dengan penerapan flipped learning ini karna dapat mengoptimalkan waktu dalam kegiatan belajar mengajar, terlebih pada MTs Al Hikmah Brebes ini dalam situasi pandemic sekolah tetap masuk secara offline tetapi tetap dengan mematuhi protocol Kesehatan dan peraturan dari pemerintah, yang mana durasi kegiatan belajar mengajar saat ini d kurangi dari yang awalnya 2x45 menit sekarang hanya 2 x 25 menit, karena harus mengurangi waktu kontak fisik secara langsung. Dengan demikian adanya penerapan model flipped classroom ini dapat memaksimalkan kegiatan pembelajaran Bahasa arab terutama dalam ketrampilan membaca. Karena ketrampilan membaca ini salah satu ketrampilan yang membutuhkan waktu banyak dalam pembelajarannya, yang mana siswa harus membaca teks bacaan harus memahami harus dapat menerjemahkan. Dengan penerapan flipped classroom ini, kegiatan didalam kelas digunakan untuk evaluasi dari materi yang sudah d tonton siswa. Lalu dalam evaluasinya guru menggunakan tes yang ditujukan kepada individu dengan tujuan untuk mengetahui pemahaman siswa sampai mana.

Dari hasil wawancara dengan siswa, siswa mengutarakan bahwa penerapan Flipped Classroom ini ada plus minus nya, yang mana dalam 
kefokusan mempelajari materi melalui Youtobe, kadang siswa terkoceh dengan tontonan lain, dan yang akhirnya siswa kurang menguasai materi yang akan di ajarkan keesokan harinya, namun ada juga siswa yang beranggapan penerapan Flipped Classroom ini sangat membantu, karena dapat leluasa memahami materi tanpa adanya batasan waktu. Jadi kapanpun dimana pun dapat mempelajari materi tersebut, dan juga dapat memudahkan siswa dalam mencari kosa kata yang ada pada materi tersebut, dengan menggunakan kamus elektronik ataupun lainnya.

Dari hasil wawancara tersebut baik guru ataupun siswa secara garis besar penerapan flipped classroom ini dapat membantu memudahakan dalam pembelajaran ketrampilan membaca, terutama dalam memahami teks bacaan. Namun ada juga sisi yang perlu diperhatikan yaitu kedisipilinan siswa dalam menonton video yang diberikan .

\section{Simpulan}

Dalam penerapan model flipped classroom terjadi peningkatan siswa dalam memahami teks bacaan. Kegiatan siswa dalam pembelajaran ketrampilan membaca ini mengalami peningkatan pada setiap pertemuan. Yang mana siswa sudah berhasil melewati beberapa indikator yang harus dicapai dalam ketrampilan membaca. Yakni siswa sudah mampu membaca dengan benar, siswa sudah mampu memahami teks bacaan juga menerjemahkan dan bercerita ulang dengan bahasanya sendiri. Begitupun dengan guru mampu mengendalikan kegiatan dalam kelas, dalam memakasimalkan interaksi antar siswa. Penerapan flipped classroom juga sangat membantu dikala kegiatan belajar mengajar berlangsung di situasi pandemic seperti ini, dengan adanya model flipped classroom dapat mekasimalkan kegaiatan belajar dikelas yang hanya terbatas oleh waktu.

Penelitian ini memiliki keterbatasan pada satu model pembelajaran saja, yaitu flipped classroom, hingga pembelajaran dengan model tersebut 
dapat berlangsung dengan maksimal pada saat itu, namun belum bias diketahui dengan menggunakan model pembelajaran yang lain. Penelitian ini menyarakan dilakukannya pembelajaran dengan model-model yang beragam, agar siswa tidak mengalami kejenuhan. Model pembelajaran yang variatif dalam melaksanakan proses belajar mengajar selain menambahkan semangat dan motivasi bagi siswa, juga membangkitkan gairah belajar, yang berujung pada mudahnya materi dapat diserap oleh siswa.

\section{Daftar Pustaka}

Alexander, P.A, and J.E Judy. n.d. "The Interaction of Domain-Specific and Strategic Knowledge in Academic Performance." Review of Educational Research, 58(4).

Arikunto, Suharsimi. 2006. Prosedur Penelitian: Suatu Pendekatan Praktik. Jakarta: Rineka Cipta.

Danker, B. 2015. "Using Flipped Classroom Approach to Explore Deep Learning in Large Classrooms |." The International Academic Forum (IAFOR) 3 (1).

Gusmadi. 2014. "Pelaksanakan Manajemen Pengawasan Pendidikan Agama Islam Di SMA Negeri Di Kabupaten Tanah Datar.” Jurnal Al-Fikrah Vol.II No 2 (July).

Iswadi, Gali, Herpratiwi Herpratiwi, and Sudirman Sudirman. 2013. "PENINGKATAN KEMAMPUAN READING COMPREHENSION MELALUI PEMBELAJARAN KOOPERATIF TIPE JIGSAW." Jurnal Tekhnologi Informasi Komunikasi Pendidikan 1(3).

Johnson, G.B. 2013. "Student Perceptions Of The Flipped Classroom." Columbia: The University Of British Columbia.

Mustofa, Syaiful. 2011. Strategi Pembelajaran Bahasa Arab Inovatif. Malang: UIN Maliki Press. 
Oktaria, Dwita, and Syahrul Hamidi. 2019. "Metode Pembelajaran Flipped Classroom Dalam Pendidikan Kedokteran." Medula Jurnal 8 No. 2.

Rohmah,Iftitahur. 2016. “FA'ALIYAHTATBIQNAMUDHAZTA'ALLUM AL-MA'KUS 'FLIPPED CLASSROOM MODEL' LITARQIYAH MAHARAH AL KITABAH LADA AT TULLAB FI AL FASHL AL TSAMIN BIMADRASAH BILINGUAL AL MUTAWASSITAH AL ISLAMIYAH PUCANG SIDOARJO.” Undergraduate, UIN Sunan Ampel Surabaya. http://digilib.uinsby.ac.id/10752/.

Sa'diyah, and Halimatus. 2019. Strategi Pembelajran Bahasa Arab Penuh Inovasi Dan Kontemporer. Nusantara Global Place : Malang.

Sugiyono. 2019. Metode Penelitian Kuantitatif, Kualitatif Dan R\&D. Bandung: Alfabeta.

Suriaman, Aminah, and Anjar Dewi. 2019. "Peningkatan Keterampilan Membaca Melalui Flipped Classroom Model.” Jurnal Kreatif Online 7 (4).

Wijaya, Mu'alim, and Nafilatul Hasanah. 2019. "Implementasi Pembeljaran Kitab Kuning Melalui Model Pembelajran Flipped Classroom." Murobbi : Jurnak Ilmu Pendidikan 3 (1): 1-20.

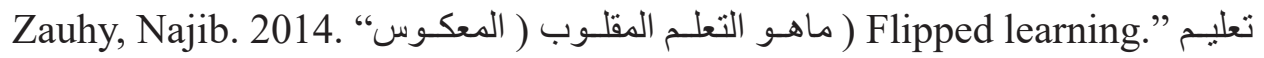
جديد (blog). February 28, 2014. https://www.new-educ.com/la-classeinversee. 